\title{
上皮小体機能立進症に㧍ける組織型と細胞活性の関連性について
}

\author{
近畿大学医学部泌尿器科学教室（主任：栗田 孝教授） \\ 高田昌彦
}

\section{THE RELATIONSHIP BETWEEN MORPHOLOGY AND CELL ACTIVITY IN HYPERPARATHYROIDISM}

\author{
Masahiko Takada \\ Department of Urology, Kinki University School of Medicine
}

(Director: Prof. Takashi Kurita)

The relationship between tissue morphology and cellular activity in hyperparathyroidism was investigated by 2-color flowcytometry and an immunohistochemical technique using anti-parathyroid hormone (PTH) antibody. A total of 21 cases were employed, which included 8 cases of primary hyperparathyroidism (PHPT) and 13 cases of secondary hyperparathyroidism (SHPT). The results of 2-color flowcytometry on DNA ploidy pattern revealed that all the 8 PHPT cases were diploids. In SHPT, however, there were 9 diploids (69.2\%), 2 tetraploids (15.4\%) and 2 aneuploids (15.4\%): Electron microscopic studies were performed on the diploid $2 \mathrm{c}$ and $4 \mathrm{c}$ peak cells, which were obtained by individually sorting the cells from each cycle. As a result, these cells were found to possess well developed rough endoplasmic reticulum and Golgi apparatus. These cells in general showed weak immunostaining. Furthermore, numerous secretory granules were found in the cells obtained from abnormal peak of aneuploid when compared to diploid cells. In tetraploids and aneuploids, the darkly stained cells and glandular cells showed intense immunostaining. These cells contained numerous secretory granules and they were thought to possess high cellular activity.

Key words: hyperparathyroidism, flowcytometry, immunostain

\footnotetext{
要旨：上皮小体機能六進症に打ける組織形態と細胞活性との関係を，抗上皮小体ホルモン (PTH) 抗体 を用いた免疫組織化学的手法と，2-color flowcytometry で検討した。対象は，原発性上皮小体機能六進 症（PHPT） 8 例，二次性上皮小体機能立進症（SHPT）13例の計21例である. 2-color flowcytometry における DNA ploidy patternの結果は，PHPTではすべて diploidを示したのに対し，SHPTでは diploid が 9 例 (69.2\%), tetraploid が 2 例 (15.4\%), aneuploid が 2 例（15.4\%）みられた。各々の

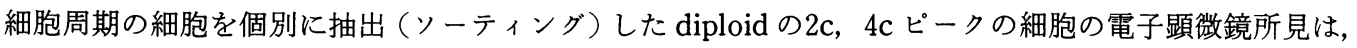
粗面小胞体の増加とゴルジ野の拡大がみられ，免疫染色では全体の細胞の染色度は一様に淡かった。 た, aneuploid の異常ピークの細胞は, diploid の細胞に比べて分泌顆粒が多数みられた。一方, tetraploid と aneuploidの免疫染色所見は, 濃く染まる細胞がみられた。これらの細胞は, 分泌顆粒を多量に有し,

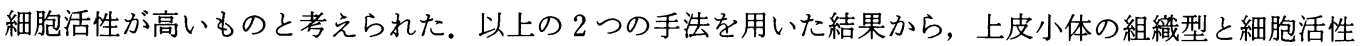
との間には，強い関連があると推察された。

キーワード：上皮小体機能穴進症, フローサイトメトリー, 免疫染色
}

上皮小体機能元進症には原発性上皮小体機能立進症 (primary hyperparathyroidism, PHPT) と二次性上 皮小体機能六進症 (secondary hyperparathyroidism, SHPT) が存在するが，これらは多くの点で異なって いる.たとえば大半の PHPT は 1 腺のみ腫大するの
に対し, SHPT では 4 腺すべてが腫大していることが 多い。組織学的にはPHPT は腺腫のことが多いのに 対し，SHPT では過形成がほとんどである。臨床症状 をみても, PHPTでは初期には無症状のことが多く, 経過と共に尿路結石や胃潰瘍をきたすが, SHPT の主 
症状である骨症状まで進行することは稀である。これ らのことから, PHPT と, SHPT は, 腫大した上皮小 体の外観上は同様に見えても，異なる細胞活性と微細 構造を持っているものと考兄られる.PHPTと SHPT の鑑別診断は基礎疾患の有無など，臨床経過か らされ，組織学的な診断は困難である122.

PHPT に打いて，血清カルシウム $(\mathrm{Ca})$ 値や上皮小 体ホルモン (Parathyroid hormone, PTH) 值に日差 変動がみられる。このことは腺腫と言えども細胞活性 やPTH 分泌能にも日差変動があるものと推察され る。さらに，一般的には上皮小体の大きさとその臨床 症状とは相関しているが，小さい上皮小体でも多彩な 症状をきたす症例もみられ，このよらな症例に接して いると，いかなる状態の上皮小体が強い細胞活性を持 ち, 臨床症状を呈するのか興味が持たれる。

最近2-color flowcytometry が開発され, 広く生物医 学に用いられている。これは, 従来の flowcytometry (FCM)で調べることができる細胞周期だけでなく, 細 胞内でのチミジンの取り込み量の違いから, その細胞 活性が解析でき; ‘おのおのの細胞周期ごとの細胞を抽 出できるンーティングも可能となり, 腫瘍などの研究 に利用されている3) 5).

上皮小体の形態についての報告1226)7)や FCM につ いての報告899 は散見されるが，この両者の関係を調べ た報告はみられない，そこで今回，上皮小体機能六進 症に拈ける組織形態と細胞活性との関係を, 抗 PTH 抗体を用いた免疫組織化学的手法と, 2-color flowcytometry で検討したので報告する。

\section{対象および方法}

対象は1988年 5 月から1990年 8 月までに手術した PHPT 8 例(男性 3 例, 女性 5 例, 平均 45.3 歳), SHPT 13例（男性 5 例, 女性 8 例, 平均 49.3 歳）の計21例で ある.PHPT はすべて結石型で， 1 腺のみの腫大で あった. SHPT では全例 4 腺の腫大を認め, 3 腺と最 も小さい腺の $1 / 2$ を摘除する上皮小体亚全摘術を施行 した。そのらち最大の 1 腺を検体に用いた。 また，平 均透析期間は 9 年間 $(7 \sim 18$ 年) であり, Ca 製剤とビ タミンDは全員内服していた。病理組織的には PHPT では 1 例の 久主細胞過形成で, 残りは腺腫で あったが, SHPT では全例主細胞過形成であった。

1. 2-color flowcytometry の検討

摘出した上皮小体を直ちに $1 \mathrm{~mm}^{3}$ 大に細切し, $0.05 \%$ コゲナーゼ加培養液にて細胞分散した。遠沈 (1,000rpm 5 分間，以下同じ）乙て上清を拾て, 培養
液内に濃度が $10 \mu \mathrm{M}$ となるよう bromodeoxyuridine (BrdU, Sigma 製)を添加し, $37^{\circ} \mathrm{C}, 95 \% \mathrm{O}_{2}, 5 \% \mathrm{CO}_{2}$ の恒温器内で30分間培養した. $\mathrm{BrdU}$ を培養液で洗浄 除去し，濃度が $0.05 \%$ となるようにラゲナーゼを加 えて細胞分散を行い, 遠沈して上清を捨て, $2 \sim 3 \mathrm{ml}$ の $70 \%$ 冷ェタノールで細胞を30分間以上固定した。遠沈 後, RNA 除去と DNA 変性処理のために3M- $\mathrm{HCl}$ で 30 分間室温にてインキュベーションし，中和のために 遠沈を繰り返してリン酸緩衝液 (phosphate buffered saline, pH 7.4, PBS) で 4 回洗浄した. 遠沈後 fluorescein isothiocyanate (FITC) 標識抗 BrdU 抗体 $20 \mu 1$ (Becton-Dickinson)を加光，30分間インキュベーショ ンした. $5 \mathrm{ml}$ の0.5\%Tween 20加 PBS を加兑て 2 回遠 沈し, PBS で $50 \mu \mathrm{g} / \mathrm{ml}$ に調製した propidium iodide を1 2ml 加光, 30 分以上静置して, 直前に $37 \mu \mathrm{m}$ ナイ ロンメッシュを通して10,000個の細胞を FCM 解析 （Becton Dickinson 社製FACScan, FACStar）した。 なお，励起波長は $488 \mathrm{~nm}, \mathrm{FL} 1$ (縦軸)の蛍光波長は5 530 $\mathrm{nm}, \mathrm{FL} 2$ (横軸) の蛍光波長は $575 \mathrm{~nm}$ で, 両者とも Band Pass フィルターを使用した. 以上の操作は室温 で施行した。

\section{2. 微細構造の検討}

cell sorter にて細胞を G 0，1期， G 2M 期の細胞, aneuploid ピークの細胞を個別に抽出し (sorting), 個々の抽出液を遠沈後 $2 \%$ グルタールアルデヒドで30 分以上固定した. PBS で洗浄し， $2 \%$ オミウムで $4{ }^{\circ} \mathrm{C}, 90$ 分間後固定のう光, 50, 70, 90, 100, 100, $100 \%$ ×ノールでそれぞれ10１5分間脱水した.プロ ピレンオキサイドで置換し，3時間浸透させ，エポキ シ樹脂に包埋し, $60^{\circ} \mathrm{C}$ にて 1 日以上重合のら方超薄切 して電子顕微鏡にて観察した。

\section{3. 免疫染色の検討}

ホルマリン固定後パラフィン包埋し, $8 \mu \mathrm{m}$ に薄切し た標本を充分に覆らように $1 \%$ 過酸化水素メタノール 液を滴下，室温にて30分インキュベーションし，PBS で洗浄, 20 倍希釈正常ヤギ血清を滴下, 室温にて 30 分 インキュベーション, PBSで洗浄し, IBL 製抗ヒト PTH ウサギ抗体, あるいは陰性コントロールとして 20 倍希釈正常ウサギ血清を滴下， $4{ }^{\circ} \mathrm{C} て ゙ 12 \sim 18$ 時間イ ンキュベーションし, PBS で洗浄, 抗ウサギ IgGヤギ 抗体を滴下, 室温で40分間インキュベーションし, PBS で洗浄後, peroxidase-anti-peroxidase 滴下 し, 室温で30分インキュベーション, 過酸化水素含有 0.01M PBS 加3-3'ジアミノベンチジン $(0.2 \mathrm{mg} / \mathrm{ml})$ 
を滴下，室温で10２0分インキュベーションし，PBS で洗浄，さらにへマトキシリンにて対比染色を施し， 脱水, 封入して検鏡した。

\section{結 果}

1. 2-color flowcytometry の検討

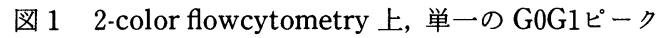
を示す diploid pattern.

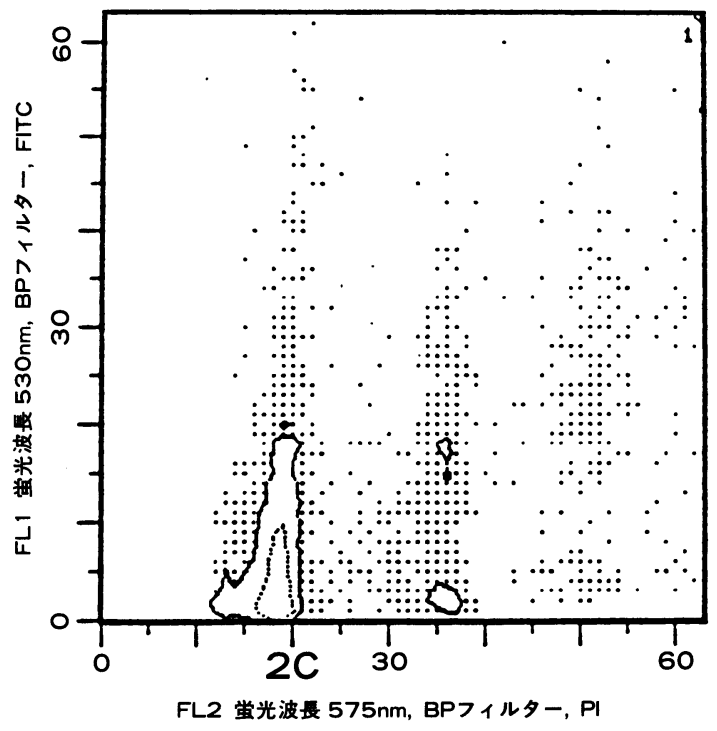

図 2 2-color flowcytometry 上, 2c に G0G1ピークを 有し，4cピークが総細胞中 $20 \%$ 以上であり，かつ tetraploidの G0G1ピークに一致する tetraploid G2, M ピークを認める tetraploid pattern.

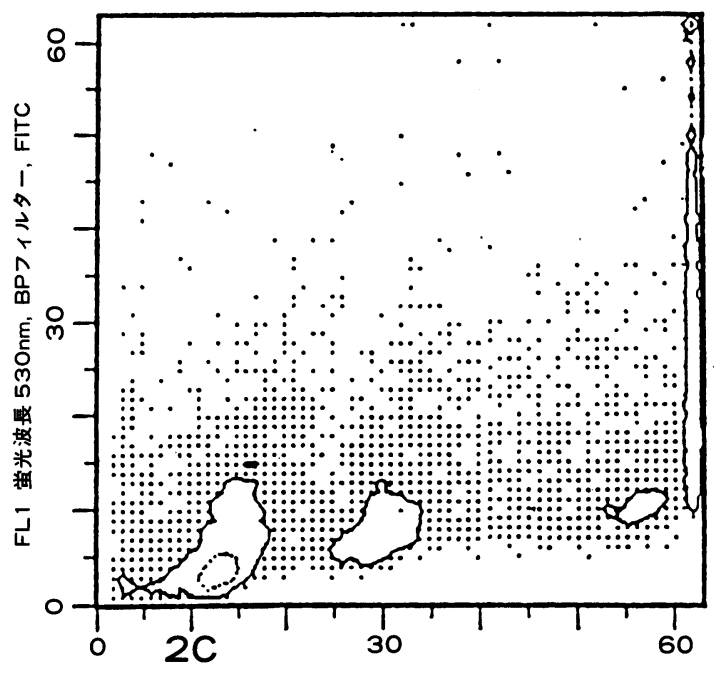

FL2 営光波長 575nm, BPフィルター, PI 2-color flowcytometry で得られたデータを解析す る際, 単一の G0G1ピークを示すものを diploid(図 1) とし，tetraploid（図 2）は2cに G0G1ピークを有し， $4 \mathrm{c}$ ピークが総細胞中 $20 \%$ 以上であり，かつ tetraploid の G0G1ピークに一致する tetraploid G2, M ピークを 認めるものとし，それ以外のものは aneuploid (図 3 ) とした.

DNA ploidy pattern の結果は, PHPT では， 1 例 の主細胞過形成症例を含め, 8 例すべて diploidを示 したのに対し，SHPT では diploid が 9 例 (69.2\%), tertaploid が 2 例 (15.4\%), aneuploid が 2 例 （15.4\%）みられた. DNA ploidy pattern と年齢，男 女差, 透析期間, 摘出腺の総重量, 血清 PTH 值, 血清 カルシゥム值との間には関係はみられなかった。ただ し，血清アルカリフォスファターゼ(Alp) 值の平均士 標準偏差(IU/L)は, diploid $280 \pm 88$ に対し, tetraploid は563，809， aneuploidは680，456といずれも高值で あった. SHPT のなかで病的骨折の既往がある症例 は，5例であったが，このらち 2 例は tetraploid， 2 例 は aneuploidを示した。

\section{2. 微細構造の検討}

diploid の2c 拈よび4c ピークのみを sorting して抽 出した上皮小体細胞の電子顕微鏡所見では，両者とも 粗面小胞体の増加, ゴルジ野の拡大がみられた(図 4 ). aneuploid の正常の2c，4cピークの細胞は diploid の

図 3 2-color flowcytometry 上, diploid でも tetraploid でもない aneuploid pattern.

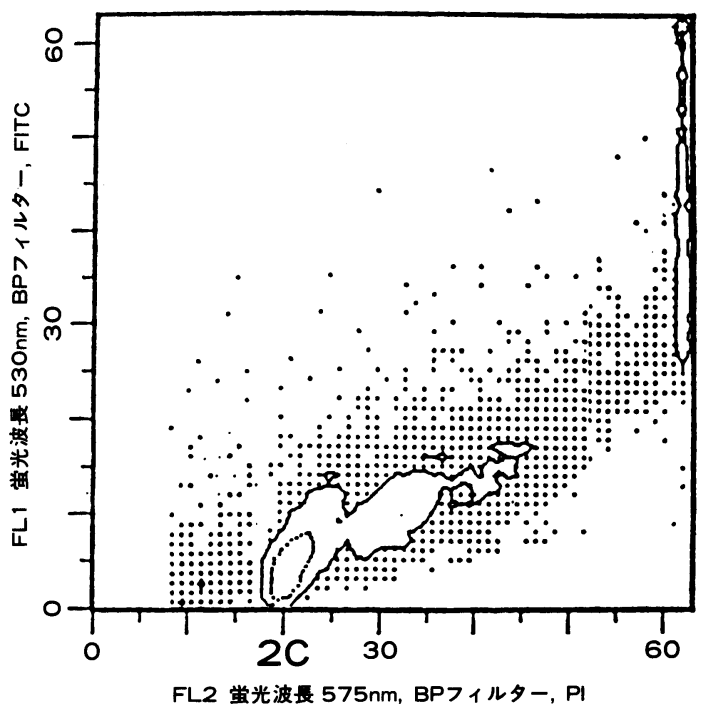


困 4 diploid の2c ピーク細胞の電子顕微鏡所見. 粗 面小胞体 (白矢印)，ゴルジ装置 (黒矢印) がみられ る $(\times 6,000)$

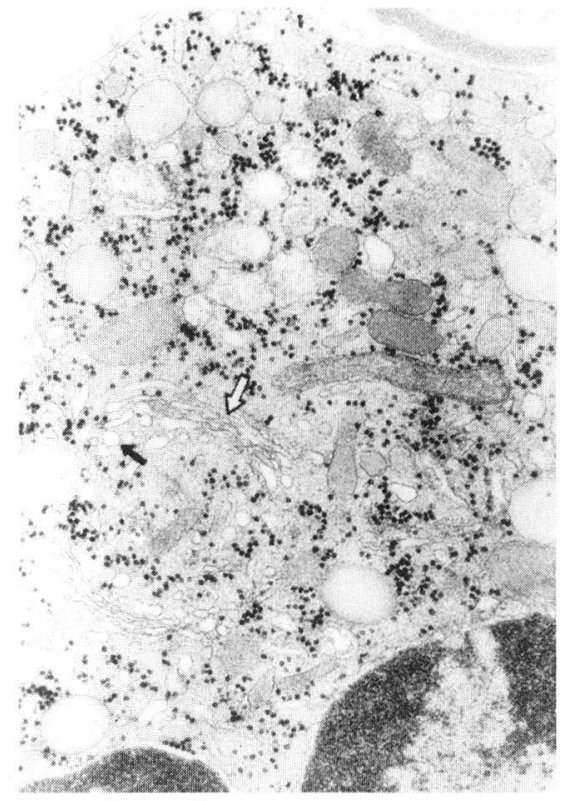

図 5 aneuploid $の$ 異常ピーク細胞の電子顕微鏡所 見. 多量の分泌顆粒がみられる。小顆粒はグリコー ゲン顆粒 $(\times 9,900)$.

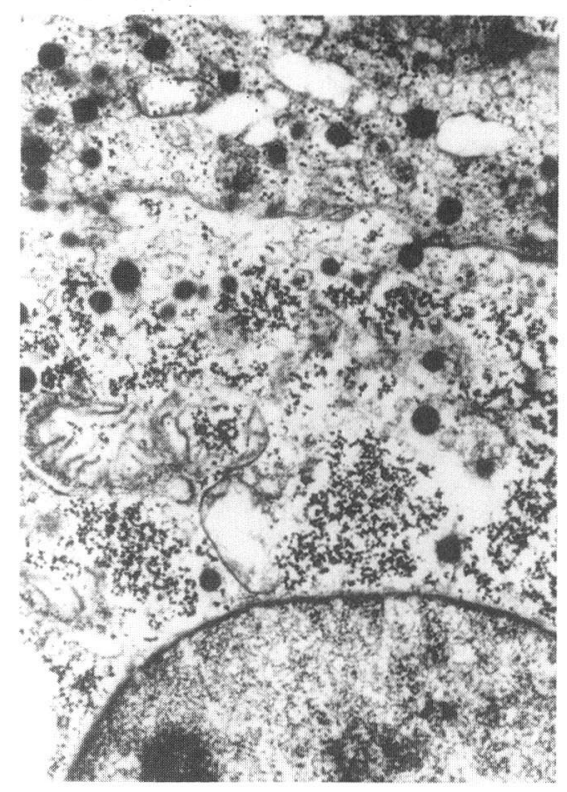

ものと同様の所見であった。一方, aneuploidの正常の $2 \mathrm{c}, 4 \mathrm{c}$ ピーク以外のピークを抽出した上皮小体細胞で
は，分泌顆粒が多数みられた（図 5 ）.

3 . 免疫染色の検討

PHPT とSHPT の所見は, diploidの上皮小体で は, 全例, 細胞質を中心に細胞全体が一様に淡く染まっ ていた（図 6-I）。この所見はPHPT（8 例）と SHPT （9 例）とで差異はなかった. tetraploid（2 例）の上 皮小体に拈いては, 腺構造の細胞が特に濃く染まった 部分がみられた（図 6-II). aneuploid（2 例）の上皮 小体では，濃く染まる細胞が散在して認められた（図 6-III)。また，陰性コントロールを図6-IVに示した。

\section{考察}

今回, 2-color flowcytometry で得られた細胞活性と 形態との関係を検討した，その結果, PHPTの 8 例で はすべて diploidであったのに対し，SHPTでは tetraploid, aneuploid がそれぞれ 2 例 (15.4\%) みら れた。また,これら 3 種類の DNA ploidy patternは, 免疫染色では異なった形態を示した。また，2-color flowcytometry で, 正常の $2 c, 4 c$ およびその他の異常 ピークを sortingして電子顕微鏡で観察したところ, 2 c, $4 \mathrm{c}$ ピークの細胞は粗面小胞体の増加やゴルジ野の 拡大などがみられた。図 4 は, 粗面小胞体の数, ゴル ジ装置の広さから, involting phase ${ }^{10)}$ に相当するもの と考えられるが， ほとんどの細胞は resting phase で はない active phaseであった，異常ピークの細胞にお いては分泌顆粒が多数認められたことから, packaging secreting phase ${ }^{10)}$ に相当するものと考えられた. 免疫染色で染色されるものは分泌顆粒であったことか $ら^{11)}$, tetraploid, aneuploid でみられた濃染細胞は, 分泌顆粒を多量に持って扣り， active phaseの中でも packaging〜 secreting phaseにあり，その細胞活性は 高く, sortingされた aneuploid の異常ピークの細胞 は, 免疫染色では濃染される細胞に相当すると考兄ら れた。

tetraploidの異常ピークは, その細胞数が少数で あったため電子顕微鏡で観察するには至らなかった が, やはり，腺構造の細胞が濃染されていることから， aneuploid と同様，分泌顆粒を多量に持った細胞であ ることが推察される。

FCM 上, tetraploid, aneuploid を示した症例は,す ベて病的骨折の既往を持っていたが, diploid 症例では 17例中 1 例しか病的骨折はなかった。病的骨折と上皮 小体細胞の細胞活性を直接結びつけることはできない が，病的骨折の原因はPTHによる骨吸収によると思 われるので, tetraploid や aneuploidを持つ上皮小体 
図 6 I ：全体の細胞が淡く染まる型 $(\times 350)$. II : 腺構造の細胞が濃く染まる型 $(\times$

$350)$. III：濃く染まる細胞が散在する型 $(\times 350)$. IV：陰性コントロール $(\times 350)$.

6-I

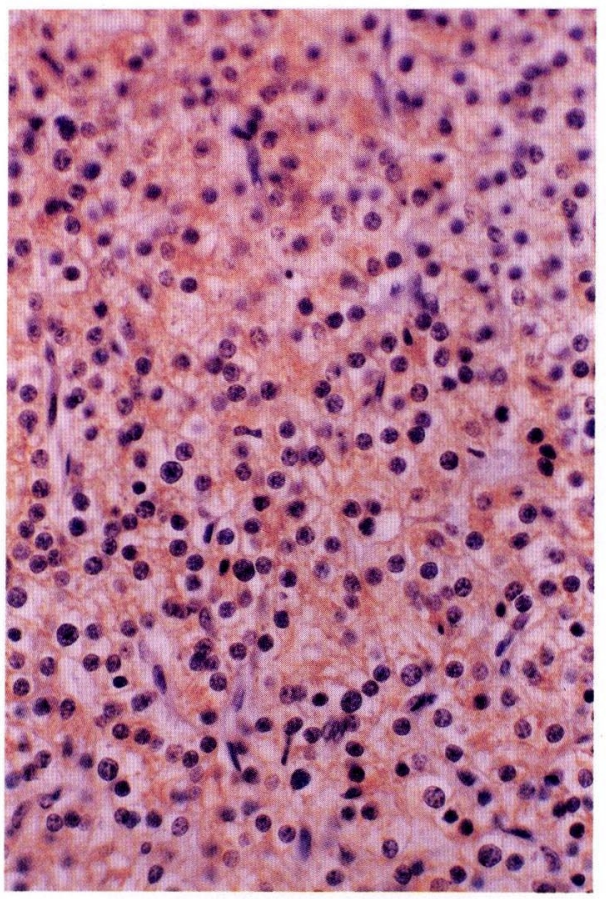

6-III

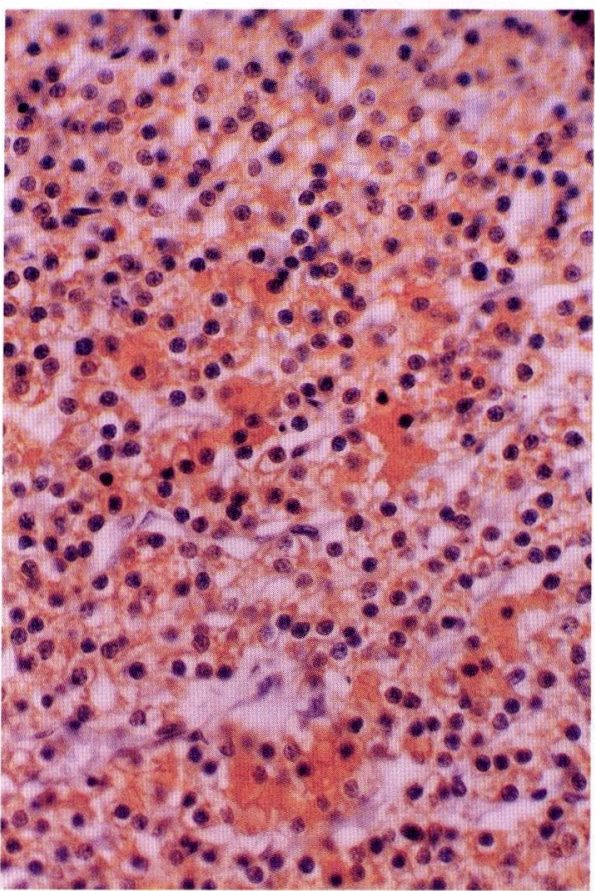

6 -II

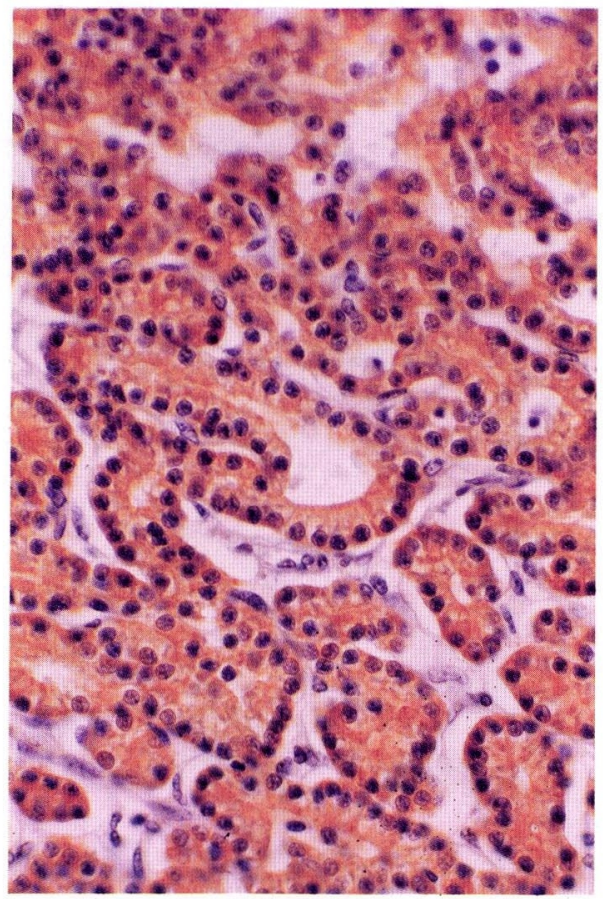

$6-\mathrm{IV}$

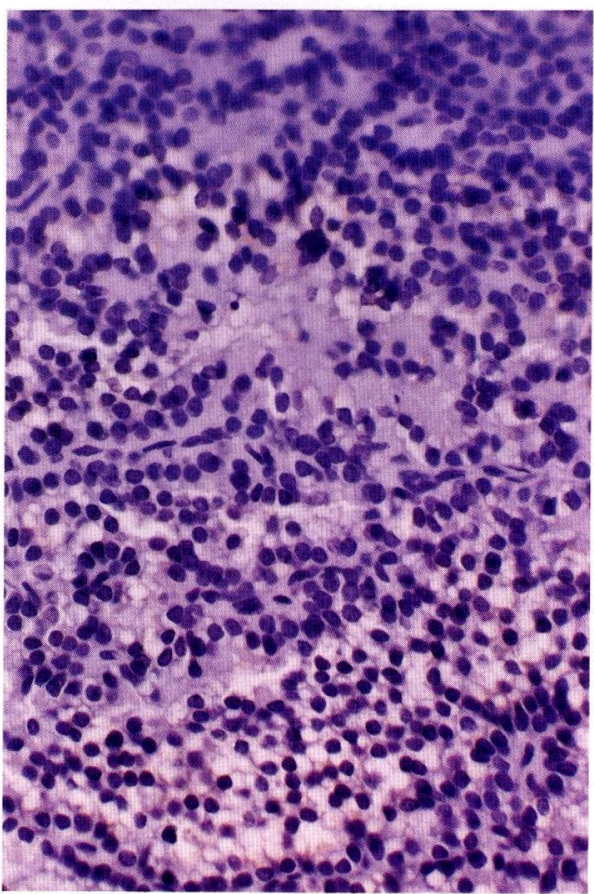


細胞の影響と考えられた。

血清 Alp 值に diploid と tetraploid および aneuploid との間で差がみられたことは, 病的骨折後の影 響とも思われるが, PTHの直接作用の可能性も考兄 られる。

今回の上皮小体の検討と同様に, 他の内分泌臓器で も病理学的に良性疾患に tetraploid や aneuploid が みられることがある12113).また, 癌でない上皮小体機能 穴進症でも，FCM 上 tetraploid や aneuploid を示す ことがあるとの報告もみられる ${ }^{899}$. しかし，今回の検 討では, diploid, tetraploid, aneuploid の間において,

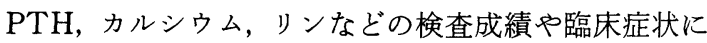
差異はなく, Alp 值と病的骨折においてのみ差異がみ られた。

同じ主細胞過形成でも DNA ploidy pattern が異な る原因は興味が持たれる。しかし，男女差，年齢，透 析期間，上皮小体の総腺重量，基礎疾患などにおいて は差異はなかった。

今回の検討で, 従来の FCM にかわって2-color flowcytometry を用いたのは, 細胞周期の違いによる細胞 を sortingすることによって各々の細胞群を電子顕微 鏡で観察する目的であったからである。ただ，tetraploid の異常ピークの細胞は観察できなかった。これ は, sorting 後, 電子顕微鏡の試料作成の過程で, 遠沈 などの操作を繰り返すことによって細胞数が減少し， 観察するに不十分であったためである.

今回, 免疫組織化学的手法と2-color flowcytometry を用いて，上皮小体の組織型と細胞活性との関連を調 べたところ，強い相関のあることが推察された。

\section{結語}

上皮小体機能え進症に抢ける組織形態と細胞活性と の関連を検討し，以下の結果を得た。

1. 2-color flowcytomeryによる上皮小体の DNA ploidy patternは, PHPTではすべて diploidであっ たが, SHPT では diploid が 9 例(69.2\%), tetraploid が 2 例 (15.4\%), aneuploid が 2 例 (15.4\%) みられ た。

2. aneuploid の異常ピークを sorting した細胞の電 顕所見では, diploid の細胞に比べて分泌顆粒が多数み られた。

3. 免疫染色の結果は, diploidの上皮小体では細胞 の染色度は一様に淡かったが, aneuploid, tetraploid の上皮小体では濃染される細胞がみられた。

4. これらの濃染細胞は, PTHの分泌顆粒を多量に
有し，高い細胞活性を持つものと考えられた。

本研究は文部省科学研究費一般研究 C (No. 62480344) 招 よび奖励研究 A（No. 02771035）による援助を受けた。

稿を終えるにあたり, 御指導, 御校閲を賜った恩師栗田 孝教授に深謝いたします。さらに直接本実験を御指導くだ さいました郡健二郎講師に厚く御礼申し上げます。

な拓, 本論文の要旨は第78回日本泌尿器科学会総会, 第 1 回日本尿路結石症研究会に扔いて発表した。

\section{文献}

1) Roth, S.I.: Recent advances in parathyroid gland pathology. Am. J. Med., 50, 612-622, 1971.

2) Lawrence, D.A.S.: A histological comparison of adenomatous and hyperplastic parathyroid glands. J. Clin. Path., 23, 626-632, 1978.

3) Horan, P.K. and Wheeless, L.L.: Quantitative single cell analysis and sorting. Science, 198, 149-157, 1977.

4）北條一夫, 遠藤 乞, 古関千寿子, 蓮村 哲, 酒井 文徳：Cell sorter (flow cytometer)を利用した Kupffer 細胞の単離とその特性. 肝臓, 23, 864-872, 1982.

5) Durand, R.E. : Use of a cell sorter for assays of cell clonogenicity. Cancer Res., 46, 2775-2778, 1986.

6) Szakacs, J.E. and Bryant, M.: Ultrastructure of parathyroid adenomas. Ann. Clin. Lab. Sci., 10, 13-25, 1980.

7) Oka T., Yoshioka, T., Shrestha, G.R., Koide, T., Sonoda, T., Hosokawa, S., Onoe, K. and Sakurai, M.: Immunohistochemical study of nodular hyperplastic parathyroid glands in patients with secondary hyperparathyroidism. Virchows Archiv. A Pathol. Anat., 413, 53-60, 1988.

8）小松 誠, 菅谷 昭, 小林 信や, 增田裕行, 高橋 昭三, 清水忠博, 飯田 太, 村松 昭: 原発性上皮 小体機能方進症における細胞核 DNA Ploidy Pattern の検討. 内分泌外科, 7, 65-69, 1990.

9) Obara, T., Fujimoto, Y., Kanaji, Y., Okamoto, T., Hirayama, A., Ito, Y. and Kodama, T.: Flow cytometric DNA analysis of parathyroid tumors -Implication of aneuploidy for pathologic and biologic classification-. Cancer, 66, 1555-1562, 1990.

10) Shannon, W.A. Jr. and Roth, S.I.: An ultrastructural study of acid phosphatase activity in normal, adenomatous and hyperplastic (chief cell type) human parathyroid glands. Am. J. Pathol., 77, 493-506, 1974.

11）高田昌彦：上皮小体機能光進症の組織分類と微細 構造について。 日泌尿会誌, 投稿中 
12）元村祐三：フローサイトメトリーによる甲状腺腫 瘍内 DNA 含量の測定一腫瘍の生物学的悪性度判 定の試み一。 日外会誌，89，1066-1074，1988.

13）中井秀郎, 橘 政昭, 馬場志郎, 出口修宏, 実川正
道, 畠亮, 田崎 寛: 正常副腎および副腎腫瘍 組織の flow cytometric DNA-histogramによる 分析. 日泌尿会誌, 80,11-16, 1989.

(1992年 8 月 3 日受理, 特別掲載) 